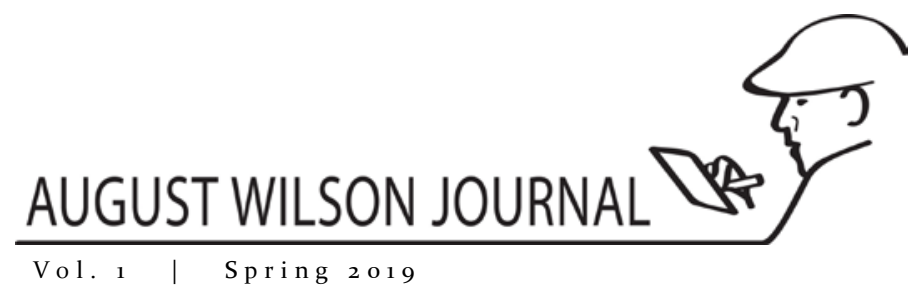

\title{
Stage Review of Fences
}

\author{
Cincinnati Shakespeare Company \\ Otto M. Budig Theater; Cincinnati Ohio \\ January 25-February 16, 2019 \\ Directed by Christopher V. Edwards
}

\author{
By Graley Herren \\ Professor of English, Xavier University
}

\begin{abstract}
The dramaturgical danger for any production of Fences is that the play will collapse into anticlimax, ending not with a bang but a whimper...
\end{abstract}

- Graley Herren

\begin{abstract}
A review of Fences by August Wilson, staged by the Cincinnati Shakespeare Company at the Otto M. Budig Theater in Cincinnati, Ohio from January 25-February 16, 2019.

Keywords

August Wilson, Fences, Cincinnati Shakespeare Company, Christopher Edwards, Raisin in the Sun, "ranney"
\end{abstract}

For over a quarter-century now, the Cincinnati Shakespeare Company has been staging some of the most provocative plays in the city. Alternating between productions of Shakespeare, non-Shakespearean classics, and creative stage adaptations of works from other media, "Cincy Shakes" (as we locals prefer to call it) is a sparkling jewel in the theatrical crown of the Queen City. On January 25, 2019, I attended the opening night of Fences, the company's first attempt at an August Wilson play.

Director Christopher V. Edwards brought back much of the cast from his successful 2017 production of A Raisin in the Sun and added in a star turn from the performer known simply as "ranney," in his CSC debut as the indomitable, infuriating, intoxicating Troy Maxson. Scenic Designer Shannon Moore gave the performers the

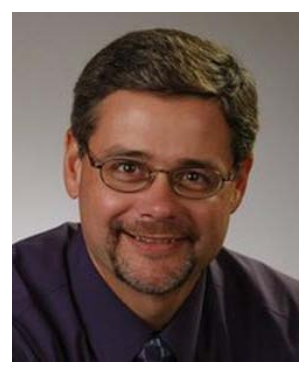

Graley Herren perfect set to work with, and Edwards chose to make the backstairs the focal point of the production. Characters were constantly bounding up and down these rickety steps, shuttling to and fro between the packed-dirt backyard and the cozy kitchen, as if crossing a bridge out of the cruel world that oppresses and denies them and into a domestic sanctuary that welcomes and revitalizes their flagging spirits. Installed as gatekeeper of this liminal threshold sat Troy Maxson, a king of shreds and patches on his hard-scrabble throne, at once the defender of the family home and the chief threat against 
it. Sometimes "ranney" sprawled out on these stairs, slugging back gin and regaling us with hilarious tall-tales. Other times he crouched and scowled like a hell-hound ready to pounce. And sometimes "ranney" sang. Damn, can that man sing! He sang the tunes marked as such in the script, but he also discovered music in other passages masquerading as prose. "ranney"s voice was a catalyst for revelation, reintroducing me to this familiar play in completely unexpected ways.

First a damning confession: I have never liked the song "Old Blue" in Fences. I mean, I get its function in the play. The song is a family heirloom passed down through the generations like the piano in The Piano Lesson. Lyrically the song makes sense. Reportedly composed by Troy's father, though in fact Wilson's variation of an old American folk song, "Old Blue" links Troy to his youth and his sharecropping roots in the rural South. Troy identifies with Blue, not just because he is "worked like a dog" and dehumanized at times by his experiences up North in industrial Pittsburgh, but also because Troy shares Blue's persistence and resilience. I get all that. I've just never heard the song delivered in ways that make it very effective musically as a song. I do appreciate the rhythm and musicality in

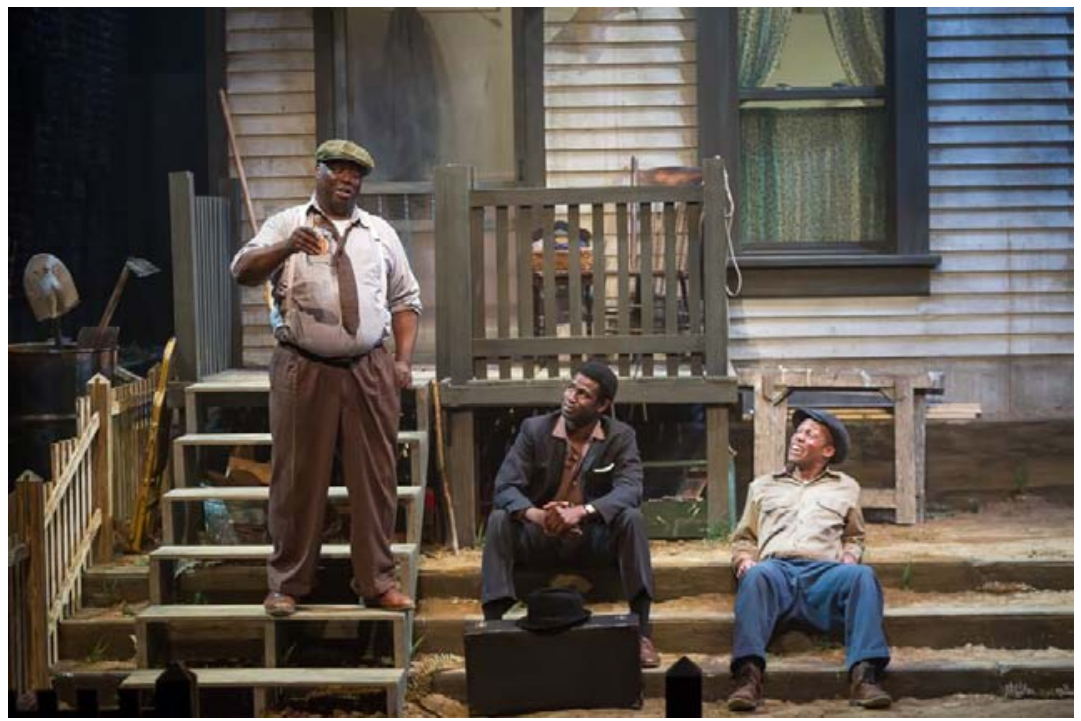

Fences at Cincinnati Shakespeare Company, 2019

Wilson's work, his great ear for dialogue and his deep inspiration from the blues. That's why it is always disappointing how flat "Old Blue" routinely falls in productions I've seen. For all their considerable talents, these past Troys just didn't have the chops to pull it off. Then I heard "ranney" sing the blues. His sonorous voice is charismatic and alluring, and he slowed the song down more than I've ever heard before. Oh. I can hear it now. "Old Blue" is not chiefly about the lyrics at all. Forget the words and the symbolism and the foreshadowing. It's aural alchemy. The song is a time machine.

I am not merely complimenting "ranney" for having a good voice and knowing how to sing the blues, though he certainly deserves that much credit and more. I'm talking instead about the way his vocal delivery helped safe-crack my appreciation for the integral part "Old Blue" plays in Fences. The song went from being a heavy-handed contrivance to serving as the glue which binds together the final scene. That scene needs glue: it's always on the verge of falling to pieces. There is of course the notorious difficulty of figuring out how to actualize Wilson's inscrutable stage directions when Gabriel (somehow!) opens the gates of heaven (a herculean task tackled with wounded dignity by Geoffrey Warren Barnes II). But the abiding challenge throughout the requiem is how to sustain momentum now that Troy is dead and gone, the pumping heart of the play stilled, and the animating life force conspicuously silent and absent. The dramaturgical danger for any production of Fences is 
that the play will collapse into anticlimax, ending not with a bang but a whimper. What fully restored the life force of CSC's Fences was the reprise of "Old Blue," first sung solo by Cory (a gripping performance by Crystian Wiltshire), and then in duet with Raynell (an utterly captivating debut by Morgan Olivia Reynolds). Again, the song has always served a clear purpose here, almost too obviously so. Cory announces he will boycott Troy's funeral; Rose can't talk him out of it (though the enchanting Torie Wiggins could coax water from a stone); then brother and sister sing their dead father's song, and it gives Cory the peace he needs to pay his final respects to Troy. So much for functionality. However, because the song has always fallen flat for me as a song, I've always had trouble accepting it as a vehicle capable of bearing the weight of such an epiphany. Not so this night at CSC, where the song opened up the play and the gates of heaven for me.

Chris Edwards's direction snatched the scene outside of naturalism for a moment. Cory and Raynell stared straight at each other in all seriousness, without either character seemingly willing it or expecting it, and without a touch of the aw-isn't-that-sweet sentimentality which sabotages this encounter in lesser productions. In this moment and through this song they channeled the spirit of dead Troy and raised him from the dead. These praise-singers echoed "ranney's" trademark cadences and slow delivery, casting a musical trance. They allowed me to finally hear what I'd been deaf to before, what I suppose had been lying dormant in the play all along. Troy's song isn't just his bridge to the past but also a premonition of the future. I don't mean that in a broad generic sense of knowing that, like all of us, he will die someday. What I mean is that "Old Blue" functions sonically and temporally much like the backstairs function spatially, as a liminal threshold, crossing dimensions and connecting worlds. When Troy sings the song earlier in the play, he is channeling that future moment when his children will sing his funeral dirge. And when Cory and Raynell later revive the song in duet, they are serving as instruments of resurrection, giving Troy life again by allowing him to sing through his descendants. Oh. So Troy is not absent from the final scene. We can't see him, but we can hear him if his song is sung right and if we know how to listen. That's the long-deferred lesson this Cincy Shakes production finally taught me. What a magical, transformative, redemptive revelation.

\section{Works Cited}

Wilson, August. Fences. Theatre Communications Group. 2007.

\section{Author Bio}

Dr. Graley Herren is Professor of English at Xavier University where he serves as Department Chair. 